\title{
REMAP-RT IN THE CIRCULATORY SYSTEM MATERIAL TO IMPROVE STUDENTS COGNITIVE LEARNING OUTPUT
}

\author{
Nuryani $^{1}$, Much Fuad Saifuddin ${ }^{2 *}$, Azkia Hasna Nuha Imana ${ }^{2}$, Devi Istiqomah ${ }^{2}$, Mia \\ Setia Haningsih ${ }^{2}$, Via Puspa Ardani ${ }^{2}$, Anita Yuni Astuti ${ }^{2}$, Destri Ratna Ma'rifah ${ }^{2}$ \\ ${ }^{1}$ SMP Muhammadiyah 2 Kalasan, Bayen, Purwomartani, Kalasan, Sleman, Daerah \\ Istimewa Yogyakarta 55571, Indonesia \\ ${ }^{2}$ Pendidikan Biologi FKIP, Universitas Ahmad Dahlan, J1 Ringroad Selatan, Kragilan, \\ Tamanan Banguntapan, Bantul, Daerah Istimewa Yogyakarta 55191, Indonesia \\ *fuad.saifuddin@pbio.uad.ac.id
}

Doi: https://doi.org/10.31943/mangiferaedu.v5i1.86

Received: February 7, 2020 Accepted: July 24, $2020 \quad$ Published: July 31, 2020

Citation: Nuryani, Saifuddin, M. F., Imana A. H. N., Istiqomah, D., Haningsih, M. S., Ardani., V. P., Astuti A. Y., Ma'rifah, D. R. (2020). REMAP-RT in the Circulatory System Material to Improve Students Cognitive Learning Output. Jurnal Mangifera Edu, 5(1), 55-63.

\begin{abstract}
Learning outcomes are still a benchmark of learning success, with good learning outcomes signifying mastery of knowledge that can be implemented in life. Students require to be accustomed to reading before beginning learning, to be able to manage information from learning resources.. This study aims to study the Remap-RT learning model to improve student learning outcomes by looking at the results of pretest and posttest students of class VIII E Muhammadiyah 2 Kalasan. The method used in this research is CAR (Classroom Action Research). The subject in this study was student at VIII E of SMP Muhammadiyah 2. Data obtained by using the test twice in both cycle, cycleI and cycle II. Based on the results of the pretest and posttest the average value of class VIII E in the last cycle is higher than the first cycle. Based on these findings it can be concluded that there is an improvement in the learning process and differences in student learning outcomes using the Remap-RT learning model.
\end{abstract}

Keywords: Models, Remap-RT, Student Learning Outcomes.

\section{ABSTRAK}

Hasil belajar masih menjadi tolak ukur keberhasilan pembelajaran, dengan hasil belajar yang baik menandakan penguasaan pengetahuan yang dapat diimplementasikan dalam kehidupan. Siswa perlu dibiasakan membaca sebelum mengawali pembelajaran, agar mampu mengelola informasi dari sumber belajar. Penelitian ini bertujuan untuk meningkatkan hasil belajar siswa dengan melihat hasil pretest dan posttest siswa kelas VIII E Muhammadiyah 2 Kalasan menggunakan model pembelajaran Remap-RT. Penelitian Tindakan Kelas ini menggunakan model Kemmis dan Taggart. Populasi dalam penelitian ini adalah siswa kelas VIII SMP Muhammadiyah 2. Kelas VIII E sebagai kelas eksperimen. Data diperoleh dengan menggunakan tes dua kali pada siklus I dan II. Berdasarkan hasil pretest dan posttest nilai rata-rata kelas VIII E dalam siklus kedua ini lebih tinggi dari siklus pertama. Berdasarkan temuan ini dapat disimpulkan bahwa ada peningkatan dalam proses 
pembelajaran dan perbedaan dalam hasil belajar siswa menggunakan model pembelajaran Remap-RT.

Kata Kunci: Model, Remap RT, Hasil Belajar Siswa.

\section{PENDAHULUAN}

Hasil belajar dapat memberikan informasi keberhasilan proses pembelajaran, upaya peningkatan kualitas pembelajaran terus dilakukan oleh setiap guru. Hasil belajar kognitif dapat membantu siswa dalam menghadapi tantangan dalam kehidupannya. Akan tetapi, sering upaya yang dilakukan guru belum sesuai dengan harapan. Hal tersebut senada dengan penelitian Aswita (2015), guru telah melakukan berbagai upaya dalam menciptakan proses pembelajaran dengan suasana yang menyenangkan namun belum menunjukkan hasil yang maksimal. Hasil belajar kognitif siswa berdasarkan hasil dokumentasi nilai-nilai yang ada belum memenuhi kriteria ketuntasan minimum (KKM). Siswa dalam proses belajar suatu materi diharapkan dapat meningkatkan pengetahuannya dan mengimplementasikan dalam kehidupan sehari-hari. Siswa dapat memperoleh pengetahuan awal dengan membaca, namun minat baca siswa cenderung rendah sehingga kurang dapat menunjang proses pembelajaran di kelas. Proses membaca sangat terkait hubungannya dengan faktor pengembangan berpikir (Pujiono, 2012).

Berdasarkan hasil wawancara kepada seorang guru IPA SMP Muhammadiyah 2 Kalasan, diungkapkan berbagai permasalahan antara lain kurangnya minat baca siswa, kurang keaktifan belajar siswa, hasil belajar siswa yang belum memenuhi KKM. Selain itu, hasil observasi dalam dua kali proses pembelajaran di kelas VIII E diperoleh informasi kreativitas siswa dan kemampuan siswa dalam membuat dan menyampaikan ide-ide juga masih sangat rendah. Guru mengungkapkan siswa kelas VIII E paling sedikit memenuhi KKM jika dibandingkan kelas lain. Guru juga mengalami kendala dalam memilih model pembelajaran untuk materi sistem peredaran darah.

Materi sistem peredaran darah bersifat abstrak sehingga memerlukan model pembelajaran yang dapat memberikan visualisasi bagi siswa. Visualisasi antara lain dapat dilakukan melalui proses membaca. Model Remap RT (Reading Concept Map Reciprocal Teaching) mengharuskan siswa untuk membaca dan membuat peta konsep secara mandiri di rumah (Pangestuti et al., 2014; Zubaidah, 2014). Kombinasi Remap dengan berbagai pembelajaran kooperatif mampu meningkatkan minat baca, hasil belajar biologi, kemampuan berpikir kritis, kesadaran metakognitif dan keterampilan metakognitif siswa (Dinnurriya et al., 2015; Pangestuti et al., 2014; Prasmala et al., 2014). 
Aktivitas membaca dan membuat peta konsep diharapkan dapat membentuk pengetahuan dasar siswa terkait materi sistem peredaran darah. Oleh karena itu, salah satu model yang dirasa tepat untuk mengatasi permasalahan di kelas tersebut adalah model Remap. Penelitian ini menggunakan Remap RT karena dapat mendukung siswa dan saling melengkapi satu sama lain. Penelitian ini untuk meningkatkan hasil belajar siswa pada materi sistem peredaran darah, sehingga dapat menyelesaikan permasahalan rendahnya KKM siswa kelas VIII E SMP Muhammadiyah 2 Kalasan.

\section{METODE PENELITIAN}

Penelitian ini menggunakan jenis penelitian tindakan kelas dengan empat tahapan pada masing-masing siklus yaitu (1) perencanaan, (2) pelaksanaan, (3) pengamatan, dan (4) refleksi (Arikunto et al., 2009). Penelitian dilaksanakan pada bulan November 2019 di SMP Muhammadiyah 2 Kalasan dengan subjek siswa kelas VIII E tahun ajaran 2019/2020 yang terdiri atas 15 laki-laki dan 17 perempuan. Kelas VIII E dipilih berdasarkan rendahnya KKM dibandingkana kelas lainnya.

Pada tahap perencanaan disusun perangkat pembelajaran. Focus Group Discussion (FGD) dilaksanakan bersama dengan dosen (1 orang) dan guru yang akan melaksanakan proses pembelajaran. Pelaksanaan proses pembelajaran dilakukan oleh guru SMP Muhammadiyah 2 Kalasan dengan tujuan untuk menghilangkan bias dari tindakan yang diberikan pada kelas objek. Pengamatan dilakukan terhadap proses pembelajaran dengan perangkat yang telah didiskusikan bersama. Refleksi dilakukan oleh guru dan lima pengamat untuk melihat ketercapaian indikator yang telah ditentukan.

Instrumen yang digunakan dalam penelitian merupakan bagian dari perangkat pembelajaran, yaitu soal tes. Soal dalam bentuk esai pada pretest dan posttest, masingmasing memuat 5 butir soal. Instrumen ini telah melalui $F G D$ sebagai langkah validasi. Instrumen yang digunakan telah diperbaiki berdasarkan masukan saat FGD. Perbaikan tersebut mencakup perbaikan dalam urutan penyajian soal sesuai level kognitif yang diukur dan perbaikan redaksional pertanyaan.

Analisis data dilakukan secara deskriptif kuantitatif dengan melihat nilai rerata kelas, persentase ketuntasan siswa secara klasikal dan peningkatan yang dicapai. Peningkatan capaian diperoleh dengan membandingkan nilai pada tiap siklus. Siswa dinyatakan tuntas apabila telah memperoleh nilai posttest di atas KKM yaitu 70. Tindakan kelas dihentikan apabila persentase ketuntasan kelas di atas $70 \%$. 


\section{HASIL DAN PEMBAHASAN}

Penelitian berlangsung dalam dua siklus pembelajaran dengan menggunakan model Remap RT. Pada proses pembelajaran pada siklus I dengan siklus II terjadi perbedaan jumlah siswa. Hal ini disebabkan karena 4 siswa tidak dapat mengikuti kegiatan pembelajaran pada siklus II sehingga data 4 siswa tersebut tidak digunakan dalam penelitian. Dari keseluruhan siswa sebanyak 32 siswa, data yang digunakan dalam penelitian berasal dari 28 siswa. Pembelajaran pada siklus I dan II diawali dengan pretest dan diakhiri dengan posttest. Pada tahapan pretest di kedua siklus diperoleh nilai rata-rata pretest yang tidak berbeda jauh yaitu 41,61 (siklus I) dan 41,79 (siklus II), hal ini menunjukkan siswa belum memiliki pengetahuan yang baik terkait dengan materi sistem peredaran darah.

Pembelajaran pada siklus I belum menunjukkan perubahan yang signifikan pada hasil belajar kognitif siswa. Hasil nilai posttest pada siklus I belum memiliki selisih kenaikan yang besar dari nilai pretest. Hal ini dilihat dari capaian nilai rerata posttest dibandingkan dengan nilai rerata pretest sebagaimana tersaji pada Tabel 1.

Tabel 1. Hasil Tes Siswa pada Siklus I

\begin{tabular}{lrc}
\hline \multicolumn{1}{c}{ Kategori tes } & Rerata Nilai & Selisih kenaikan \\
\hline Pretest & 41,61 & \multirow{2}{*}{14,11} \\
Postest & 55,71 & \\
\hline
\end{tabular}

Berdasarkan hasil rerata nilai postest pada Tabel 1, nilai rerata tes siswa belum mencapai batas masih berada di bawah KKM. Nilai pretest terendah adalah 20 dan nilai tertinggi adalah 70. Nilai posttest terendah adalah 40 dan nilai tertinggi adalah 80 . Berdasarkan nilai postest yang diperoleh dapat diketahui ketuntasan belajar yang dicapai siswa. Hasil ketuntasan tersaji pada Tabel 2.

Tabel 2. Ketuntasan Belajar Siswa pada Siklus I

\begin{tabular}{lrr}
\hline \multicolumn{1}{c}{ Kriteria } & Banyak siswa & Persentase (\%) \\
\hline Tuntas & 4 & 14 \\
Belum Tuntas & 24 & 86 \\
Jumlah & 28 & 100 \\
\hline
\end{tabular}

Berdasarkan Tabel 2, dilakukan refleksi terhadap proses pembelajaran yang dilaksanakan pada siklus I. Refleksi pada siklus I mengungkap beberapa temuan antara lain: 1) proses pembelajaran dengan model Remap $R T$ belum berjalan secara maksimal, yang ditunjukkan dengan siswa belum mampu menyerap, menganalisis dan menerapkan pembelajaran mengenai sistem peredaran darah tersebut ke dalam bentuk pembelajaran yang berupa mind map. 2) Siswa yang belum terbiasa membuat mind map sehingga perlu 
diberikan contoh pembuatan mind map terlebih dulu untuk proses pembelajaran pada siklus II.

Hasil refleksi siklus I selanjutnya digunakan dalam memantapkan persiapan dan pelaksanaan pembelajaran siklus II. Hasil pada siklus II diperoleh selisih antara nilai pretest dan posttest semakin melebar. Hal ini dapat dicermati pada Tabel 3.

Tabel 3. Hasil Tes Siswa pada Siklus II

\begin{tabular}{lrc}
\hline \multicolumn{1}{c}{ Kategori tes } & Rerata Nilai & Selisih kenaikan \\
\hline Pretest & 41,79 & \multirow{2}{*}{43,93} \\
Posttest & 85,71 & \\
\hline
\end{tabular}

Ketuntasan belajar siswa juga meningkat pada siklus II. Tabel 4 menunjukkan banyaknya siswa yang tuntas dalam pengerjaan soal posttest di siklus II.

Tabel 4. Ketuntasan Belajar Siswa pada Siklus II

\begin{tabular}{lrr}
\hline \multicolumn{1}{c}{ Kriteria } & Banyak siswa & Persentase (\%) \\
\hline Tuntas & 23 & 82 \\
Belum Tuntas & 5 & 18 \\
Jumlah & 28 & 100 \\
\hline
\end{tabular}

Peningkatan hasil belajar siswa pada siklus I ke siklus II tampak jelas pada hasil posttest siswa. Peningkatan ini sebesar 30 poin. Persentase ketuntasan belajar siswa juga mengalami peningkatan dari $14 \%$ menjadi $82 \%$. Peningkatan hasil belajar kognitif siswa dapat diamati pada Gambar 1.

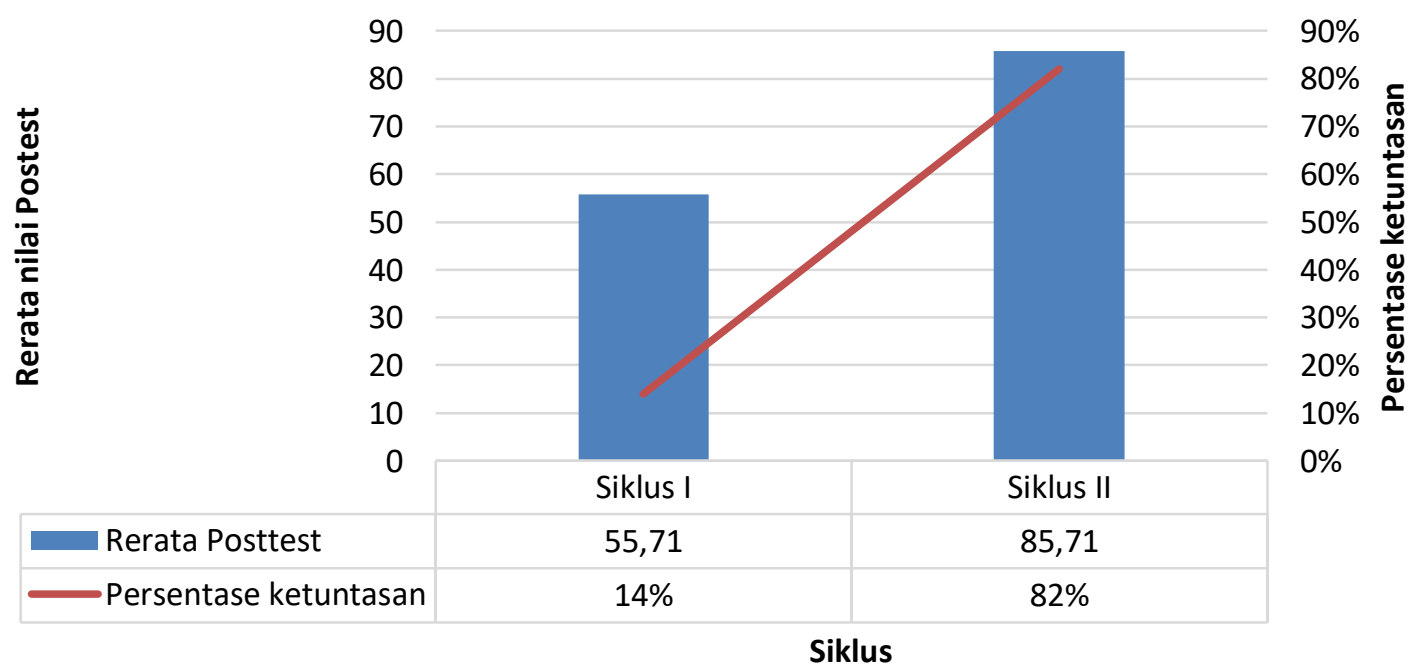

\section{Gambar 1. Peningkatan Hasil Belajar Kognitif Siswa}

Pada siklus II, materi pembelajaran sistem peredaran darah selanjutnya mencakup materi organ, sistem organ dan gangguan pada sistem peredaran darah. Pada siklus II hasil nilai pretest dan posttest siswa kelas VIII E di SMP Muhammadiyah 2 Kalasan menunjukkan 
kenaikan hasil yang cukup signifikan. Berdasarkan hasil dari pelaksanaan siklus II, diketahui bahwa hasil belajar siswa kelas VIII E di SMP Muhammadiyah 2 Kalasan mengalami peningkatan yang cukup signifikan pada materi sistem peredaran darah. Peningkatan hasil belajar tersebut menunjukkan bahwa model pembelajaran Remap RT (Reading Concept Map Reciprocal Teaching), adanya peningkatan hasil belajar sangat didukung dengan sintak pembelajaran yang menekankan siswa untuk membaca terlebih dahulu sebelum menyajikan ide/gagasan pokok dari materi yang dipelajari dalam bentuk mind map. Salah satu strategi terbaik untuk memperoleh pengetahuan dan pembelajaran adalah dengan cara membaca, dimana membaca mempunyai tujuan utama mengembangkan keterampilan pemahaman (Tavsancil et al., 2019). Seseorang yang tidak memiliki keterampilan membaca yang cukup (lambat, stagnan, dan salah pengkodean) akan menghambat kontraksi informasi individu menjadi makna yang lebih besar (Voß \& Blumenthal, 2020)

Pengalaman belajar selanjutnya yang diperoleh siswa setelah membaca adalah menyusun mind map. Mind map merupakan sarana atau alat untuk mengorganisir dan menggambarkan pengetahuan (Novak \& Cañas, 2008). Mind map dapat mengarahkan cara berpikir siswa untuk membentuk suatu pengetahuan yang sistematis dan benar. Hal ini sebagaimana disampaikan oleh Llewellyn (2013), mind map adalah sebuah cara peta pikiran yang menuntun cara berpikir kita. Siswa dapat memanfaatkan mind map yang dibuat sebagai sarana belajar dan bertukar informasi kepada siswa lain.

Kemampuan siswa dalam membuat mind map sebagai sarana belajar pada pembelajaran materi sistem peredaran darah dapat terlihat pada Gambar 2. Mind map yang dibuat oleh siswa lebih variatif jika dibandingkan yang biasa terdapat dalam buku biologi maupun LKS.
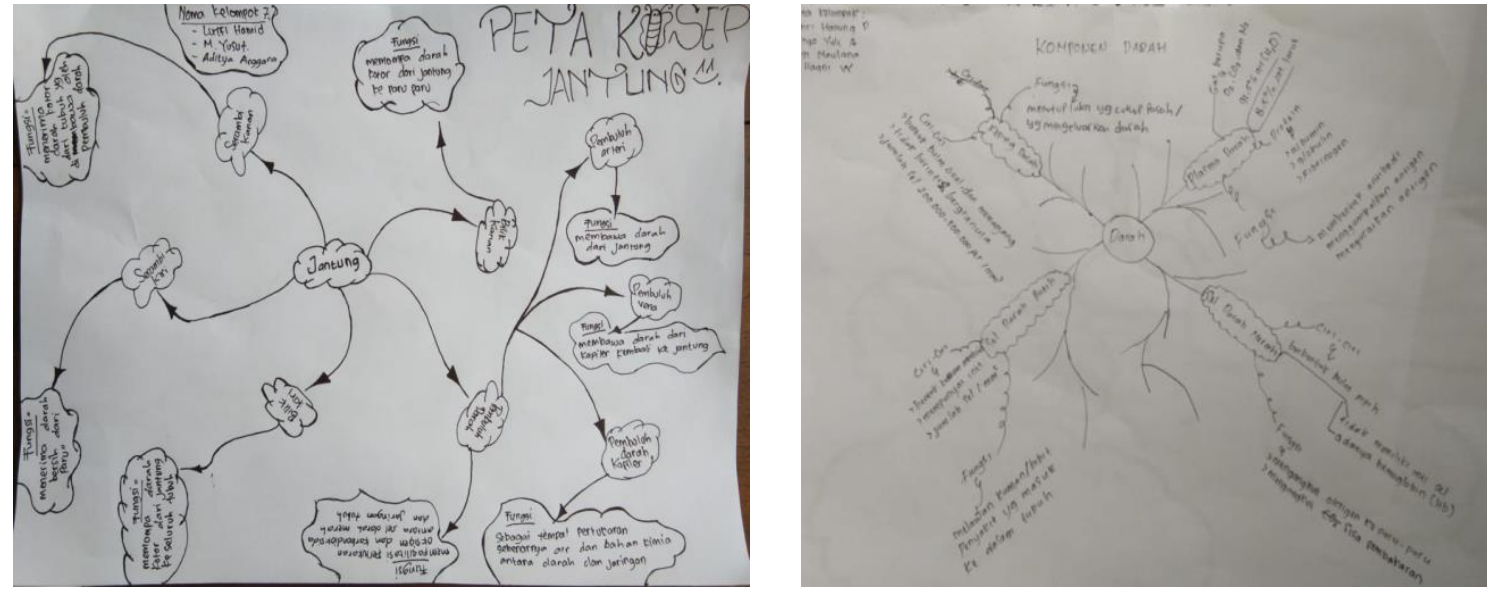

Gambar 2. Hasil Mind Map Siswa 
Lebih lanjut, Vanides, et al., (2005) menyampaikan bahwa mind map memberikan siswa kesempatan untuk: 1) memikirkan tentang hubungan antara konsep sains yang sedang dipelajari; 2) mengorganisasi gagasan dan memvisualisasikan hubungan antara konsep inti dengan cara sistematik, dan 3) merefleksi pemahaman konsepnya. Jadi, mind map memungkinkan siswa untuk berpikir secara mendalam tentang sains dengan cara membantu siswa untuk lebih baik lagi memahami dan mengorganisir apa yang telah mereka pelajari dan untuk menyimpan dan memunculkan kembali memori tentang materi pelajaran tersebut secara efisien. Dengan demikian, melalui penggunaan mind map siswa tidak hanya sekedar mengetahui dan memahami suatu konsep saja, melainkan juga dapat menerapkan maupun menganalisis hubungan antar konsep yang mana termasuk ke dalam kemampuan berpikir kritis.

Mind map yang telah dibuat sangat membantu siswa dalam aktivitas tahapan Reciprocal Teaching, siswa menjadi lebih mudah memahami informasi penting yang melalui media mind map. Selain itu siswa mampu lebih mudah menyusun pertanyaan berdasarkan informasi kata kunci yang ada dalam mind map. Guru ataupun siswa lain dapat melakukan klarifikasi terkait dengan konsep atau kata yang belum dipahami, dan siswa mampu untuk mengaitkan antara kata kunci satu dengan yang lain sehingga membentuk pengetahuan yang utuh terkait dengan materi sistem peredaran darah.

Hasil refleksi pada siklus II, diperoleh informasi proses pembelajaran telah mencapai kriteria ketuntasan minimal. Selain itu, siklus II telah memenuhi indicator yang telah ditetapkan dalam penelitian tindakan kelas ini. Hasil belajar menunjukkan terdapat 5 siswa yang belum memenuhi KKM, kecenderungan dari 5 siswa tersebut memiliki pola belajar yang lebih lambat dibandingkan siswa lainnya. Hal ini dapat digunakan oleh peneliti lain untuk membuat pemetaan karakteristik siswa dalam belajar sehingga dapat digunakan dalam berbagai penelitian yang terkait dengan pembelajaran.

\section{SIMPULAN}

Model pembelajaran Remap RT yang diterapkan di kelas VII E SMP Muhammadiyah 2 Kalasan pada materi sistem peredaran darah mata pelajaran Ilmu Pengetahuan Alam dapat meningkatkan hasil belajar kognitif siswa. Sebaiknya dilakukan indentifikasi karakteristik siswa dalam belajar untuk menjadi acuan bagi guru dalam memilih model dan media pembelajaran yang akan digunakan dalam proses pembelajaran. 


\section{DAFTAR PUSTAKA}

Arikunto, S., Suhadjono, S., \& Supardi, S. (2009). Penelitian Tindakan Kelas (Revisi). Jakarta: Bumi Aksara.

Aswita, D. (2015). Identifikasi Masalah yang Dihadapi Guru Biologi dalam Pelaksanaan Pembelajaran pada Materi Ekosistem. Jurnal Biotik, 3(1), 63-68. https://jurnal.arraniry.ac.id/index.php/biotik/article/view/993

Dinnurriya, M. S., Zubaidah, S., \& Mahanal, S. (2015). Pengaruh Model Pembelajaran Biologi Berbasis Reading-Concept Map-Numbered Heads Together (Remap NHT) Terhadap Minat Baca, Kemampuan Metakognitif, Keterampilan Berpikir Kritis dan Hasil Belajar Kognitif Siswa Kelas X SMA Malang. Disertasi. Universitas Negeri Malang. http://karya-ilmiah.um.ac.id/index.php/disertasi/article/view/41789

Llewellyn, D. (2013). Teaching High School Science Through Inquiry and Argumentation $(2$ ed.). https://books.google.co.id/books?id=bks4DQAAQBAJ\&lpg=PP1\&ots=VI7fx9KeH5 \&dq=Teaching High School Science Throuh Inquiry and Argumentation\&lr\&pg=PR4\#v=onepage\&q=Teaching High School Science Throuh Inquiry and Argumentation\&f=false

Novak, J. D., \& Cañas, A. J. (2008). The Theory Underlying Concept Maps and How to Construct and Use Them, Technical Report IHMC CmapTools 2006-01 Rev 01-2008. http://www.ssu.ac.ir/fileadmin/templates/fa/Moavenatha/MoavenateAmozeshi/edicupload/olymp-3.pdf

Pangestuti, A. A., Susilo, H., \& Zubaidah, S. (2014). Penerapan Model Pembelajaran Biologi Berbasis Reading-Concept Map-Teams Games Tournaments untuk Meningkatkan Minat Baca, Kemampuan Berpikir Kritis, Metakognitif, dan Hasil Belajar Kognitif Siswa Kelas X IPA 4 SMA Laboratorium UM. Proceeding Biology Education Conference, 963-968. https://jurnal.uns.ac.id/prosbi/article/view/7962

Prasmala, E. R., Zubaidah, S., \& Mahanal, S. (2014). Penerapan Model Reading Map Group Investigation (Gi) untuk Meningkatkan Minat Baca, Kemampuan Berpikir Kritis, Kesadaran Metakognitif dan Hasil Belajar Biologi Siswa Kelas X SMA Surya Buana Malang. Skripsi. Universitas Negeri Malang. Diambil dari http://library.um.ac.id/ptk/index.php?mod=detail\&id=65505

Pujiono, S. (2012). Berpikir Kritis dalam Literasi Membaca dan Menulis untuk Memperkuat Jati Diri Bangsa. Prosiding Bahasa dan Sastra Indonesia, 778-783. http://staffnew.uny.ac.id/upload/132318127/penelitian/Berpikir+Kritis+dalam+Pembe 1+Membaca+dan+Menulis+(Prisiding++PIBSI).pdf

Tavsancil, E., Yildirim, O., \& Demir, B. S. (2019). Direct and Indirect Effects of Learning Strategies and Reading Enjoyment on PISA 2009 Reading Performance. Eurasian Journal of Educational Research, (82), 169-190. https://doi.org/10.14689/ejer.2019.82.9

Vanides, J., Yin, Y., Tomita, M., Ruiz-Primo, \& Araceli, M. (2005). Using concept map in the science classroom. https://bcpsodlpd.pbworks.com/w/file/fetch/82996531/Concept 
Jurnal Mangifera Edu, Volume 5, Nomor 1, Juli 2020, 55-63

Mapping Article.pdf

Voß, S., \& Blumenthal, Y. (2020). Assessing the Word Recognition Skills of German Elementary Students in Silent Reading-Psychometric Properties of an Item Pool to Generate Curriculum-Based Measurements. Education Sciences, 10(2), 35. https://doi.org/10.3390/educsci10020035

Zubaidah, S. (2014). Pemberdayaan Keterampilan Penemuan dalam Scientific Approach melalui Pembelajaran Berbasis Remap Coople. Proceeding Biology Education Conference, 1000-1011. https://jurnal.uns.ac.id/prosbi/article/view/7970 